\title{
Role of vitamin D, serum zinc, and serum iron deficiency in community-acquired pneumonia in children
}

\author{
Asmaa Alhusseiny Ahmed Alsharkawy ${ }^{1}$ and Ahmed R. Rezk ${ }^{2^{*}}$ (D)
}

\begin{abstract}
Background: Community-acquired pneumonia is a major cause of death among children. Inadequate nutrition disrupts the immune system and increases the susceptibility to infections. We aimed to evaluate the association between vitamin $\mathrm{D}$, serum zinc, and iron, and pneumonia. A case-control study was conducted at the outpatient clinic and emergency room of Children's Hospital. Thirty-one patients with community-acquired pneumonia and 36 healthy children (control group) underwent serum sampling for vitamin D, zinc, and iron.

Results: Most patients had mild form $(n=17,54.8 \%)$. All patients survived and were discharged. The serum iron level showed a non-significant difference between pneumonia and control groups ( $p>0.05$ ). TIBC, vitamin D, and serum zinc were significantly lower in the patient group than the control group $(P$ value $=0.04,<0.001$, and 0.03 , respectively). Vitamin $D$ deficiency was highly associated with the severity of pneumonia ( $P$ value $=0.008$ ).

Conclusion: Adequate serum zinc and vitamin D levels may be protective against infection with communityacquired pneumonia in children aged from 2 months to 5 years old, but not iron.
\end{abstract}

Keywords: Community-acquired pneumonia, Iron, Pediatrics, Vitamin D, Zinc

\section{Background}

Community-acquired pneumonia (CAP) is defined as an acute infection of the pulmonary parenchyma in a previously healthy child who has not resided in a hospital in the preceding 14 days [1]. Approximately, 150 million cases of childhood community-acquired pneumonia have been reported each year [2]. Pneumonia remains the major single cause of death in children outside the neonatal period, causing approximately 900,000 of the estimated 6.3 million child deaths in 2013 [1]. In Egypt, the incidence of pneumonia has been estimated at 0.10.2 pneumonia episodes per child-year [3]. Inadequate nutrition and acute lower respiratory infection are overlapping and interrelated health problems affecting children in developing countries [4].

\footnotetext{
*Correspondence: ahmed_rezk@med.asu.edu.eg

${ }^{2}$ Department of Pediatrics, Intensive care unit, Ain Shams University

Hospitals, Cairo, Egypt

Full list of author information is available at the end of the article
}

Vitamin D has many important functions not only for calcium and bone homeostasis but also for immunity and antimicrobial response. For innate immunity, macrophages recognize pathogen-associated molecular patterns such as lipopolysaccharides and flagellin by tolllike receptors (TLR). TLR binding leads to a series of events that result in the production of bactericidal peptides such as cathelicidin and beta-defensin 4 , and it also increases the expression of vitamin D receptors [5]. Vitamin $\mathrm{D}$ binding enhances the transcription of the genes of cathelicidin and beta-defensin 4 [6]. Vitamin D deficiency in addition to its relation to the development of rickets has been reported to be a major risk factor for CAP [2].

Iron is a necessary element for immune system integrity. It is important for immune cell proliferation and differentiation and enzyme production against pathogens [7]. Its deficiency has been related to many infections including CAP [8].

\section{Springer Open}

(c) The Author(s). 2021 Open Access This article is licensed under a Creative Commons Attribution 4.0 International License, which permits use, sharing, adaptation, distribution and reproduction in any medium or format, as long as you give appropriate credit to the original author(s) and the source, provide a link to the Creative Commons licence, and indicate if changes were made. The images or other third party material in this article are included in the article's Creative Commons licence, unless indicated otherwise in a credit line to the material. If material is not included in the article's Creative Commons licence and your intended use is not permitted by statutory regulation or exceeds the permitted use, you will need to obtain permission directly from the copyright holder. To view a copy of this licence, visit http://creativecommons.org/licenses/by/4.0/. 
Table 1 Characteristics of the study population

\begin{tabular}{|c|c|c|c|c|c|}
\hline & & Patient group $(N=31)$ & Control group $(N=36)$ & Test value & $P$ value \\
\hline Age (months) & Median (IQR) & $12(4-17)$ & $10.5(6-26)$ & $-0.327^{* *}$ & 0.743 \\
\hline \multirow[t]{2}{*}{ Sex } & Male & $15(48.4 \%)$ & $17(47.2 \%)$ & $0.009^{*}$ & 0.924 \\
\hline & Female & $16(51.6 \%)$ & 19 (52.8\%) & & \\
\hline Weight centile & Median (IQR) & $50(25-50)$ & 75 (50-90) & $-3.246^{* *}$ & $0.001^{\prime}$ \\
\hline Height centile & Median (IQR) & $25(25-50)$ & $50(50-75)$ & $-3.441^{* *}$ & $0.001^{\prime}$ \\
\hline \multirow[t]{4}{*}{ Type of feeding } & Breast & $11(35.5 \%)$ & $8(22.2 \%)$ & $3.756^{*}$ & 0.289 \\
\hline & Artificial & $3(9.7 \%)$ & $8(22.2 \%)$ & & \\
\hline & Weaned & $12(38.7 \%)$ & $17(47.2 \%)$ & & \\
\hline & Mixed & $5(16.1 \%)$ & $3(8.3 \%)$ & & \\
\hline
\end{tabular}

${ }^{*}$ Chi-square test

**Mann-Whitney

Zinc is an essential nutrient for normal immune system activity [9]. Zinc deficiency is associated with increased risk of infection, particularly pneumonia and diarrhea [10]. Children are more prone to zinc deficiency and this is attributed to the fact that they are less able to absorb dietary zinc and some children, especially in lowincome countries, may not have received enough zinc from their mothers before birth [11].

In our study, we aimed to assess the association between serum zinc, iron, and vitamin D deficiency and community-acquired pneumonia among children. We, also, targeted to identify the most related nutrient deficiency to infection development and progression.

\section{Methods}

This case-control study included 67 individuals, 31 with community-acquired pneumonia and 36 healthy (control group), admitted at the outpatient clinic and emergency room of Children's Hospital, from January 2019 to June 2019. Informed consent was obtained from the parents or guardians of all participants for admission to the hospital and the procedures performed during hospitalization. Ethical approval was obtained from the research ethics board. This study was conducted under the Declaration of Helsinki.

Inclusion criteria were patients aged 2 months up to 5 years who suffered CAP according to British Thoracic Society (BTS) criteria [12]. Patients were clinically classified according to the severity of pneumonia. Mild to moderate cases had temperature $<38.5{ }^{\circ} \mathrm{C}$, respiratory rate $<50$ breaths/min, and mild breathlessness. Severe cases had temperature $>38.5{ }^{\circ} \mathrm{C}$, respiratory rate $>50$ breaths/min, severe difficulty in breathing, nasal flaring, cyanosis, and tachycardia according to age. We excluded patients with nosocomial pneumonia or any cardiac, neurological, musculoskeletal, hepatic, or renal disease.

All participants were exposed to detailed medical and breastfeeding history, complete clinical examination. Investigations included chest X-ray anteroposterior view, complete blood count using Sysmex KX-2IN automated hematology analyzer, and C-reactive protein using Avitex CRP latex. We measured serum calcium, phosphate, and alkaline phosphatase in addition to vitamin D3 levels using high-performance liquid chromatography (HPLC). Serum zinc level measurement was done on a 5010-spectrophotometer supplied by Roche Diagnostics (GmbH, Sandhofer Strasse 116, D-68305 Mannheim) using zinc fluid monoreagent supplied by Centronic GmbH (Kleinfeld 11, 85456 Wartenberg/Germany).

Serum iron assay analysis was done on a 5010spectrophotometer supplied by Roche Diagnostics using a total iron chromazurol B single reagent supplied by Spectrum (Schiffgraben 4130175 Hannover, Germany). Serum TIBC analysis was done on a 5010spectrophotometer supplied by Roche Diagnostics (GmbH, Sandhofer Strasse 116, D-68305 Mannheim) using saturation and precipitation methods supplied by GPL (CHEMELEX, S.A. Pol. Ind. Can Castells. C/Industrial 113, Nau J - 08420 Canovelles -BARCELONA SPAIN). Transferrin saturation percentage was calculated as the value of serum iron divided by the total iron-binding capacity of the available transferrin. We excluded serum ferritin despite it is the most specific for identifying iron deficiency anemia as it is an acute-phase reactant, and its levels may be elevated under certain conditions such as infection and inflammation.

Table 2 Distribution of severity, and fate, and mortality among the patient group $(n=31)$

\begin{tabular}{llll}
\hline & & No. & $\%$ \\
\hline Severity & Mild & 17 & $54.8 \%$ \\
& Moderate & 10 & $32.3 \%$ \\
\multirow{3}{*}{ Fate and mortality } & Severe & 4 & $12.9 \%$ \\
& Admitted again & 1 & $3.2 \%$ \\
& Discharged & 30 & $96.8 \%$ \\
\hline
\end{tabular}


Table 3 Serum iron, TIBC, transferrin saturation, and adequacy of iron level and TIBC compared to normal levels

\begin{tabular}{|c|c|c|c|c|c|}
\hline & & \multirow{2}{*}{$\begin{array}{l}\text { Patient group } \\
\text { No. }=31\end{array}$} & \multirow{2}{*}{$\begin{array}{l}\text { Control group } \\
\text { No. }=36\end{array}$} & \multicolumn{2}{|c|}{ Independent $t$ test } \\
\hline & & & & $\bar{t}$ & $P$ value \\
\hline S. iron $(\mu \mathrm{g} / \mathrm{dL})$ & Mean \pm SD & $127.54 \pm 31.68$ & $138.17 \pm 40.39$ & -1.185 & 0.240 \\
\hline \multirow[t]{2}{*}{ Iron level } & Adequate & $31(100.0 \%)$ & $36(100.0 \%)$ & NA & NA \\
\hline & Inadequate & $0(0.0 \%)$ & $0(0.0 \%)$ & & \\
\hline $\mathrm{TIBC}(\mu \mathrm{g} / \mathrm{dL})$ & Mean \pm SD & $580.05 \pm 126.68$ & $519.69 \pm 109.43$ & 2.093 & 0.040 \\
\hline \multirow[t]{2}{*}{ TIBC } & Adequate & $4(12.9 \%)$ & $8(22.2 \%)$ & 0.984 & 0.321 \\
\hline & Inadequate & 27 (87.1\%) & $28(77.8 \%)$ & & \\
\hline Transferrin saturation & Mean \pm SD & $0.26 \pm 0.10$ & $0.24 \pm 0.08$ & 0.643 & 0.522 \\
\hline
\end{tabular}

\section{Statistical analysis}

The collected data were revised, coded, tabulated, and computed using Statistical Package for Social Science (IBM SPSS) version 15 using appropriate statistical methods. Data were presented as mean, standard deviation, and range when parametric and median with interquartile range with non-parametric. For quantitative data with parametric distribution, an independent $t$ test and one-way analysis of variance (ANOVA) were employed, while for non-parametric data, the MannWhitney test was used. Categorical variables were compared using the Chi-square test. Power analysis was performed before patient recruitment to validate that the sample size was sufficient to back the statistical significance of the study outcomes with a confidence interval of $95 \%$ and a margin of error of $5 \%$. A $P$ value $\leq 0.05$ was considered statistically significant.

\section{Results}

The study was conducted on 67 participants; 15 males and 16 females were in the patient group, and 17 males and 19 females were in the control group. The difference in age, sex, and type of feeding between the two groups were insignificant $(P$ values $>0.05)$ but the weight and height were significantly lower among the patient group (Table 1).

Table 2 demonstrates the severity level of pneumonia among the patient group, most patients had mild form $(n=17,54.8 \%)$. All patients survived and were discharged.
Serum iron level and transferrin saturation demonstrated a non-significant difference between the pneumonia group and the control group. However, TIBC was significantly lower in the patient group than in the control group $(P$ value $=0.04)$. All subjects in our study had adequate serum iron levels (Table 3 ).

Vitamin D and serum zinc were significantly lower in the patient group than the control group ( $p$ value < 0.001 and 0.03 , respectively) (Tables 4 and 5).

Among the patient group, the levels of serum iron, TIBC, and transferrin saturation were not related to the severity level of pneumonia $(P$ values $>0.05)$ as well, the levels of serum zinc, calcium, phosphate, and alkaline phosphatase. However, vitamin D deficiency was highly associated with the severity of pneumonia (Table 6). Table 7 shows that all patients with severe pneumonia had deficient vitamin $\mathrm{D}$.

In Table 8, the combined inadequacy of vitamin D and TIBC was significantly low in the patient group suggesting their strong association in pneumonia development.

\section{Discussion}

Pneumonia is one of the major causes of childhood death. Many factors have an impact on the pathogenesis and clinical course of pneumonia. We targeted to evaluate the effect of serum iron, vitamin D, and zinc deficiency and identify the most related nutrient deficiency to pneumonia.

In our study, we evaluated the iron profile and the possible impact on pneumonia. We found that $64.5 \%$ of

Table 4 Serum vitamin D level and comparison to normal range

\begin{tabular}{|c|c|c|c|c|c|}
\hline & & \multirow{2}{*}{$\begin{array}{l}\text { Patient } \\
\text { group } \\
\text { No. }=31\end{array}$} & \multirow{2}{*}{$\begin{array}{l}\text { Control } \\
\text { group } \\
\text { No. }=36\end{array}$} & \multicolumn{2}{|c|}{ Independent $t$ test } \\
\hline & & & & $t / X^{2 *}$ & $P$ value \\
\hline Vit. D (nmol/L) & Mean \pm SD & $37.32 \pm 20.56$ & $82.50 \pm 30.74$ & -6.949 & $0.000^{\prime}$ \\
\hline \multirow[t]{3}{*}{ Vit. D level } & Sufficient & $6(19.4 \%)$ & $31(86.1 \%)$ & $32.254^{*}$ & $0.000^{\prime}$ \\
\hline & Insufficient & $13(41.9 \%)$ & $5(13.9 \%)$ & & \\
\hline & Deficient & $12(38.7 \%)$ & $0(0.0 \%)$ & & \\
\hline
\end{tabular}


Table 5 Serum zinc level and comparison to normal range

\begin{tabular}{|c|c|c|c|c|c|}
\hline & & Patient & & Indepen & \\
\hline & & $\begin{array}{l}\text { group } \\
\text { No. }=31\end{array}$ & $\begin{array}{l}\text { group } \\
\text { No. }=36\end{array}$ & $\bar{t}$ & $P$ value \\
\hline S. zinc $(\mu \mathrm{g} / \mathrm{dL})$ & Mean \pm SD & $114.29 \pm 45.01$ & $145.01 \pm 64.69$ & -2.220 & $0.030^{\prime}$ \\
\hline Zinc level & Adequate & $25(80.6 \%)$ & 33 (91.7\%) & 1.740 & 0.187 \\
\hline & Inadequate & $6(19.4 \%)$ & $3(8.3 \%)$ & & \\
\hline
\end{tabular}

cases had hemoglobin level $<11 \mathrm{gm} / \mathrm{dl}$ which might indicate a strong association between iron deficiency anemia and the CAP. El-Sakka et al. stated that a low hemoglobin level is a risk factor for acute lower respiratory infections as it was detected in $62.5 \%$ of pneumonia patients [13]. Similarly, Hussain et al. reported that $64.5 \%$ of their hospitalized patients and $28.2 \%$ of the healthy controls were anemic and that the anemic children were 4.6 times more susceptible to lower respiratory tract infection [14].

In the current study, there was no relation between hemoglobin level and the severity of pneumonia (Table 6). In contrast, Coles, Malla, and Shallans' studies reported an association between low hemoglobin levels and pneumonia severity [15-17].

In our study, there was no association between serum iron level and community-acquired pneumonia; however, the TIBC was more in the pneumonic group. Although these findings may be against the physiological facts during infection, yet maybe the small sample size and other causes of anemias had an effect. (Table 3)

Vitamin D was significantly lower among the patient group than in the control group (Table 4). Vitamin D levels correlated with the severity of pneumonia in the studied population (Table 6). Kulkarni and Chougule as well as Jovanovich et al. reported that there was a high association between vitamin D deficiency and community-acquired pneumonia in pediatrics $[18,19]$.

A study noted that $74 \%$ of children with severe pneumonia had rickets as defined by low or normal calcium, low phosphorous, and high serum alkaline phosphatase [20]. Even subclinical vitamin D deficiency was found to be associated with severe acute lower respiratory infection in children less than 5 years of age [21]. The association of vitamin $\mathrm{D}$ deficiency and lower respiratory tract infections is not only limited to children but is also found among newborns, infants, and adults [22].

Zinc level was significantly lower in the patient group than in the control group which means that inadequate serum zinc level is associated with community-acquired pneumonia (Table 5). A study reported that the zinc level in peripheral blood was reduced in $76 \%$ of critically ill infants with community-acquired pneumonia [23]. Barnett et al. found that zinc supplementation had a beneficial effect on the clinical course and incidence of pneumonia [24]. Also, Arica et al. demonstrated that there was a significant relationship between the plasma levels of zinc and the susceptibility to pneumonia in children aged 0-24 months; moreover, zinc may be more protective in children whose immune systems are not fully developed [25]. Another study reported that high levels of zinc in pediatric patients with pneumonia could lower the incidence and prevalence of pneumonia, days of hospitalization, and improve the clinical outcome [26].

In contrast, Saleh et al. reported that there is no relation between zinc levels and community-acquired pneumonia [27]. Also, on the contrary, Vinayak and Behal found that a course of zinc supplementation

Table 6 Laboratory values among the patient group are classified according to pneumonia severity

\begin{tabular}{|c|c|c|c|c|c|}
\hline & Mild $(n=17)$ & Moderate $(n=10)$ & Severe $(n=4)$ & One-way ANOVA test value & $P$ value \\
\hline Hemoglobin & $10.10 \pm 1.23$ & $10.95 \pm 1.40$ & $0.18 \pm 0.92$ & 1.496 & 0.241 \\
\hline Iron $(\mu \mathrm{g} / \mathrm{dL})$ & $125.67 \pm 30.49$ & $133.67 \pm 31.67$ & $120.15 \pm 43.00$ & 0.311 & 0.735 \\
\hline $\mathrm{TIBC}(\mu \mathrm{g} / \mathrm{dL})$ & $526.31 \pm 130.00$ & $516.24 \pm 44.65$ & $500.18 \pm 151.13$ & 0.094 & 0.911 \\
\hline Transferrin saturation & $0.26 \pm 0.12$ & $0.26 \pm 0.06$ & $0.26 \pm 0.14$ & 0.002 & 0.998 \\
\hline Vit. D (nmol/L) & $47.12 \pm 22.92$ & $27.20 \pm 7.50$ & $21.00 \pm 4.24$ & 5.811 & 0.008 \\
\hline $\operatorname{Zinc}(\mu \mathrm{g} / \mathrm{dL})$ & $105.65 \pm 46.65$ & $125.34 \pm 33.81$ & $123.38 \pm 65.44$ & 0.681 & 0.514 \\
\hline $\mathrm{Ca}^{2++}(\mathrm{mg} / \mathrm{dl})$ & $8.20 \pm 1.40$ & $8.04 \pm 1.39$ & $9.08 \pm 0.68$ & 0.896 & 0.419 \\
\hline Phosphate (mg/dl) & $4.67 \pm 1.42$ & $4.75 \pm 0.63$ & $3.75 \pm 1.32$ & 1.091 & 0.350 \\
\hline Alkaline phosphatase (IU/L) & $313.88 \pm 150.89$ & $296.50 \pm 119.93$ & $223.25 \pm 75.28$ & 0.729 & 0.491 \\
\hline
\end{tabular}


Table 7 Serum iron, serum vitamin D, and serum zinc levels compared to normal range in different severity of pneumonia

\begin{tabular}{|c|c|c|c|c|c|c|}
\hline & & Mild $(n=17)$ & Moderate $(n=10)$ & Severe $(n=4)$ & Chi-square test value & $P$ value \\
\hline \multirow[t]{2}{*}{ Iron level } & Adequate $(60-170 \mu \mathrm{g} / \mathrm{dl})$ & $17(100.0 \%)$ & $10(100.0 \%)$ & $4(100.0 \%)$ & NA & NA \\
\hline & Inadequate & $0(0.0 \%)$ & $0(0.0 \%)$ & $0(0.0 \%)$ & & \\
\hline \multirow[t]{3}{*}{ Vit. D level } & Sufficient (' 60 nmol/L) & $6(35.3 \%)$ & $0(0.0 \%)$ & $0(0.0 \%)$ & 15.360 & 0.004 \\
\hline & Insufficient (30-60 nmol/L) & $9(52.9 \%)$ & $4(40.0 \%)$ & $0(0.0 \%)$ & & \\
\hline & Deficient (<30 nmol/L) & $2(11.8 \%)$ & $6(60.0 \%)$ & $4(100.0 \%)$ & & \\
\hline \multirow[t]{2}{*}{ Zinc level } & Adequate $(70-120 \mu \mathrm{g} / \mathrm{dl})$ & $12(70.6 \%)$ & $10(100.0 \%)$ & $3(75.0 \%)$ & 3.583 & 0.167 \\
\hline & Inadequate & $5(29.4 \%)$ & $0(0.0 \%)$ & $1(25.0 \%)$ & & \\
\hline
\end{tabular}

Table 8 Comparison between patient and control groups as regard combined zinc and vitamin D inadequate levels, combined zinc and TIBC inadequate levels, combined vitamin D and TIBC inadequate levels, inadequate all of them, and sufficient all of them

\begin{tabular}{|c|c|c|c|c|c|c|}
\hline & \multicolumn{2}{|c|}{ Patient group } & \multicolumn{2}{|c|}{ Control group } & \multicolumn{2}{|c|}{ Chi-square test } \\
\hline & No. & $\%$ & No. & $\%$ & $\overline{x^{2}}$ & $P$ value \\
\hline Combined inadequate zinc and vit. D & 0 & $0.0 \%$ & 0 & $0.0 \%$ & 0.000 & 1.000 \\
\hline Combined inadequate zinc and TIBC & 2 & $6.5 \%$ & 2 & $5.6 \%$ & 0.024 & 0.877 \\
\hline Combined inadequate vit. $\mathrm{D}$ and TIBC & 17 & $54.8 \%$ & 4 & $11.1 \%$ & 14.800 & 0.000 \\
\hline Inadequate zinc, vit. D, and TIBC & 2 & $6.5 \%$ & 1 & $2.8 \%$ & 0.526 & 0.468 \\
\hline Inadequate one of them & 10 & $32.3 \%$ & 21 & $58.3 \%$ & 4.555 & 0.033 \\
\hline Sufficient all of them & 0 & $0.0 \%$ & 8 & $22.2 \%$ & 7.823 & 0.005 \\
\hline
\end{tabular}


for patients with pneumonia, aged up to 5 years, did not have a significant effect and recommended that it should not be proposed for adjuvant therapies and so no relation between serum zinc level and pneumonia [28].

We found that serum vitamin $\mathrm{D}$ is the most important single relative risk factor for acquiring CAP in comparison to the zinc level followed by TIBC (Table 8).

The results of the current study are limited by the small sample size, short duration of follow-up, and the lack of age subgrouping. Further studies are recommended to ensure the accuracy of our findings.

\section{Conclusion}

In the view of our study, we can conclude that adequate serum zinc, vitamin $\mathrm{D}$ levels may be protective against infection with community-acquired pneumonia in children aged from 2 months to 5 years old. However, we could not prove that adequate serum iron levels may reduce community-acquired pneumonia affecting the same age group. We recommend supplementation of zinc, vitamin $\mathrm{D}$, and iron to maintain the integrity of the immune system and as prophylaxis against pneumonia.

\section{Abbreviations}

CAP: Community-acquired pneumonia; BTS: British Thoracic Society; TIBC: Total iron blood capacity; TLR: Toll-like receptor

\section{Acknowledgements}

Not applicable.

\section{Authors' contributions}

AA has put the study design, collected data, and shared in drafting. AR shared in the study design, drafted the manuscript, and performed the statistical analysis. All authors read and approved the final manuscript.

\section{Funding}

No funding was received.

\section{Availability of data and materials}

The datasets used and/or analyzed during the current study are available from the corresponding author on reasonable request.

\section{Declarations}

\section{Ethics approval and consent to participate}

Obtained from Ain Shams University, Faculty of Medicine, Research Ethics Board ID number 30-19-872. Written informed consent was obtained from the parents of each child enrolled in the study.

\section{Consent for publication}

Not applicable.

\section{Competing interests}

The authors declare that they have no competing interests.

\section{Author details}

'Department of Pediatrics, Chest Unit, Ain Shams University Hospitals, Cairo, Egypt. ${ }^{2}$ Department of Pediatrics, Intensive care unit, Ain Shams University Hospitals, Cairo, Egypt.
Received: 17 June 2021 Accepted: 19 July 2021

Published online: 16 August 2021

\section{References}

1. Kyu HH, Pinho C, Wagner JA et al (2016) Global and national burden of diseases and injuries among children and adolescents between 1990 and 2013: findings from the Global Burden of Disease 2013 Study. JAMA Pediatr 170(3):267-287. https://doi.org/10.1001/jamapediatrics.2015.4276

2. Zhou Y-F, Luo B-A, Qin L-L (2019) The association between vitamin D deficiency and community-acquired pneumonia: a meta-analysis of observational studies. Medicine (Baltimore) 98(38):e17252. https://doi.org/10.1 097/MD.0000000000017252

3. Fadl N, Ashour A, Yousry MY (2020) Pneumonia among under-five children in Alexandria, Egypt: a case-control study. J Egypt Public Health Assoc 95(1): 14. https://doi.org/10.1186/s42506-020-00043-0

4. Roth DE, Caulfield LE, Ezzati M, Black RE (2008) Acute lower respiratory infections in childhood: opportunities for reducing the global burden through nutritional interventions. Bull World Health Organ 86(5):356-364. https://doi.org/10.2471/blt.07.049114

5. Gallo RL, Murakami M, Ohtake T, Zaiou M (2002) Biology and clinical relevance of naturally occurring antimicrobial peptides. J Allergy Clin Immunol 110(6):823-831. https://doi.org/10.1067/mai.2002.129801

6. Liu PT, Stenger S, Li H et al (2006) Toll-like receptor triggering of a vitamin D-mediated human antimicrobial response. Science. 311(5768):1770-1773. https://doi.org/10.1126/science.1123933

7. Beard JL (2001) Iron biology in immune function, muscle metabolism and neuronal functioning. J Nutr 131(2):568S-580S. https://doi.org/10.1093/ jn/131.2.568S

8. Budnevsky A V, Esaulenko IE, Ovsyannikov ES, Labzhaniya NB, Voronina E V, Chernov A V. [Anemic syndrome in patients with community-acquired pneumonia]. Klin Med (Mosk). 2016;94(1):56—60. http://europepmc.org/a bstract/MED/27172725

9. Basnet S, Mathisen M, Strand TA (2015) Oral zinc and common childhood infections--an update. J trace Elem Med Biol organ Soc Miner Trace Elem 31: 163-166. https://doi.org/10.1016/j.jtemb.2014.05.006

10. Krebs NF, Miller LV, Hambidge KM (2014) Zinc deficiency in infants and children: a review of its complex and synergistic interactions. Paediatr Int Child Health 34(4):279-288. https://doi.org/10.1179/2046905514Y.0000000151

11. Lassi ZS, Moin A, Bhutta ZA (2016) Zinc supplementation for the prevention of pneumonia in children aged 2 months to 59 months. Cochrane Database Syst Rev 12(12):CD005978. https://doi.org/10.1002/14651858.CD005978.pub3

12. Society BT, Group CG. British Thoracic Society guidelines for the management of community acquired pneumonia in childhood. Thorax. 2002:57 Suppl 1(October).

13. El Sakka AS, Imam SS, Amer HA, Moustafa SA (2014) Vitamin D deficiency and low hemoglobin level as risk factors for severity of acute lower respiratory tract infections in Egyptian children: a case-control study. Egypt Pediatr Assoc Gaz 62(1):1-7. https://doi.org/10.1016/j.epag.2013.12.001

14. Hussain SQ, Ashraf M, Wani JG, Ahmed J (2014) Low hemoglobin level a risk factor for acute lower respiratory tract infections (ALRTI) in children. J Clin Diagn Res 8(4):PC01-PC03. https://doi.org/10.7860/JCDR/2014/8387.4268

15. Coles CL, Fraser D, Givon-Lavi N, Greenberg D, Gorodischer R, Bar-Ziv J, Dagan R (2005) Nutritional status and diarrheal illness as independent risk factors for alveolar pneumonia. Am J Epidemiol 162(10):999-1007. https:// doi.org/10.1093/aje/kwi312

16. Malla T, Pathak O, Malla K. Is low hemoglobin level a risk factor for acute lower respiratory tract infections? J Nepal Paediatr Soc. 2009;30(1 SE-Original Articles). doi:https://doi.org/10.3126/jnps.v30i1.2453

17. SHALLAN IM, Azeem HA, Al-Sayed MT. Iron deficiency anemia as a risk and prognostic factor of community acquired pneumonia. In: ; 2016.

18. Kulkarni SP, Chougule AA (2017) Correlation of serum vitamin D levels and anemia in childhood pneumonia: a case control study from rural area. Int J Contemp Pediatr 4(3):756. https://doi.org/10.18203/2349-3291.ijcp20171075

19. Jovanovich AJ, Ginde AA, Holmen J, Jablonski K, Allyn R, Kendrick J, Chonchol M (2014) Vitamin D level and risk of community-acquired pneumonia and sepsis. Nutrients. 6(6):2196-2205. https://doi.org/10.3390/ nu6062196

20. Haider N Nagi AG, Khan KMA (2010) Frequency of nutritional rickets in children admitted with severe pneumonia. J Pak Med Assoc 60(9):729-732

21. Wayse V, Yousafzai A, Mogale K, Filteau S (2004) Association of subclinical vitamin D deficiency with severe acute lower respiratory infection in Indian 
children under 5 y. Eur J Clin Nutr 58(4):563-567. https://doi.org/10.1038/sj. ejcn.1601845

22. Holter JC, Ueland T, Norseth J, Brunborg C, Frøland SS, Husebye E, Aukrust $P$, Heggelund L (2016) Vitamin D status and long-term mortality in community-acquired pneumonia: secondary data analysis from a prospective cohort. PLoS One 11(7):e0158536. https://doi.org/10.1371/journa I.pone.0158536

23. Yuan X, Qian SY, Li Z, Zhang ZZ (2016) Effect of Zinc supplementation on infants with severe pneumonia. World J Pediatr 12(2):166-169. https://doi. org/10.1007/s12519-015-0072-9

24. Barnett JB, Dao MC, Hamer DH, Kandel R, Brandeis G, Wu D, Dallal GE, Jacques PF, Schreiber R, Kong E, Meydani SN (2016) Effect of zinc supplementation on serum zinc concentration and T cell proliferation in nursing home elderly: a randomized, double-blind, placebo-controlled trial1. Am J Clin Nutr 103(3):942-951. https://doi.org/10.3945/ajcn.115.115188

25. Arica S, Arica V, Dag H et al (2011) Serum zinc levels in children of 0-24 months diagnosed with pneumonia admitted to our clinic. Int I Clin Exp Med 4(3):227-233

26. Zhou W, Zuo X, Li J, Yu Z (2016) Effects of nutrition intervention on the nutritional status and outcomes of pediatric patients with pneumonia. Minerva Pediatr 68(1):5-10

27. Saleh P, Sadeghpour A, Mirza-Aghazadeh-Attari M, Hatampour M, NaghaviBehzad M, Tabrizi A (2017) Relationship between plasma levels of zinc and clinical course of pneumonia. Tanaffos. 16(1):40-45

28. Vinayak $R$, Behal $M$. Role of zinc as an adjuvant therapy in severe pneumonia - a double blind placebo controlled randomized clinical trial. Panacea J Med Sci 2015;5(August):61-72.

\section{Publisher's Note}

Springer Nature remains neutral with regard to jurisdictional claims in published maps and institutional affiliations.

\section{Submit your manuscript to a SpringerOpen ${ }^{\circ}$ journal and benefit from:}

- Convenient online submission

- Rigorous peer review

- Open access: articles freely available online

- High visibility within the field

- Retaining the copyright to your article

Submit your next manuscript at $\boldsymbol{\nabla}$ springeropen.com 